\title{
Facilitators and Barriers in Applying Building Information Modeling (BIM) for Construction Industry
}

\author{
Min-Ho Shin ${ }^{1}$ D and Hwan-Yong Kim ${ }^{2, *}$ (D) \\ 1 Department of Railroad Construction System Engineering, Woosong University, 171 Dongdaejeon-ro, \\ Dong-gu, Dejeon 34606, Korea; minhoshin57@wsu.ac.kr \\ 2 School of Architecture \& Architectural Engineering, Hanyang University ERICA, 55 Hanyangdaehak-ro, \\ Snagnok-gu, Ansan 15588, Korea \\ * Correspondence: hwankim@hanyang.ac.kr; Tel.: +82-31-400-5135
}

Citation: Shin, M.-H.; Kim, H.-Y Facilitators and Barriers in Applying Building Information Modeling (BIM) for Construction Industry. Appl. Sci. 2021, 11, 8983. https://doi.org/ 10.3390/app11198983

Academic Editor: Asterios Bakolas

Received: 23 August 2021

Accepted: 23 September 2021

Published: 27 September 2021

Publisher's Note: MDPI stays neutral with regard to jurisdictional claims in published maps and institutional affiliations.

Copyright: (C) 2021 by the authors Licensee MDPI, Basel, Switzerland. This article is an open access article distributed under the terms and conditions of the Creative Commons Attribution (CC BY) license (https:// creativecommons.org/licenses/by/ $4.0 /)$.

\begin{abstract}
AbstractsThe authors provide a holistic perspective to enhance BIM working environment for more efficient smart construction settlements. An in-depth survey with 40 questionnaires was distributed to 100 professionals in construction, design, engineering, government. Although $45 \%$ of the respondents have received a certain form of BIM education, more than $94 \%$ of the respondents have answered that there should be a formal BIM education. Both design and construction experts have reported that the biggest advantage of using BIM is in its error checking ability. It can reduce design errors and increase construction ability. More than $79 \%$ of the respondents agreed upon a proper compensation for BIM implementation. The majority of opinions have revealed that there should be an increase in construction and design fees. There are a number issues for a successful BIM application: (1) guidelines and details for BIM work and delivery; (2) more standardized BIM education; and (3) a proper compensation system for BIM work. The results show that BIM professionals are ready to adopt the consequences of using BIM, but administrative and institutional preparations are not available beforehand. There should be a higher level of regulatory concern and provision of administrative solutions for successful BIM applications.
\end{abstract}

Keywords: Building Information Modeling (BIM); smart construction; survey analysis; BIM environments; rail BIM

\section{Introduction}

Recent technological improvements have made rapid changes in construction industry. This is especially true in database management and data sciences. In specific, technical applications, such as Building Information Modeling (BIM) or Geographic Information Systems (GIS), opened up many possibilities for construction management. As many have noted, BIM provides nD Computer-Aided Drawing (CAD) services that are traditionally not available in many cases [1-3]. It means BIM is an effective tool to manage construction process in a timely manner, and its information-oriented interface is a powerful tool for every step in construction [4-6]. With its 3-dimensional ability along with versatility to control a vast amount of associated data, BIM is regarded as a key ingredient in future construction industry.

Active utilization of data management in construction industry received more attention than before because of the new technological approach, known as "smart construction". Smart construction became a new phenomenon in many countries, especially in Japan, South Korea, and the United Kingdom [7,8]. Because it is a relatively new term, smart construction has a range of definitions. In brief, it can be divided into two segments. First, smart construction enables construction process in a more automated manner. By using Internet-of-Things (IoT) and other sensing devices, construction equipment can operate automatically, without demanding human involvements $[9,10]$. This process can greatly reduce human errors and enhance work environment more safely. The other root of smart construction is founded on 
data management and utilization. Because new applications, such as BIM, GIS, and others are available for data management and creation; planning, designing, construction, and operation can be done in a more 3D-friendly way $[8,11,12]$. By reducing the use of $2 \mathrm{D}$ works, users can enjoy less errors and eventually could provide a better risk management. In this paper, the authors focus more on the second segment of smart construction because BIM became an essential tool to operate data-concentrated construction process and eventually, is the key for a successful smart construction implementation.

The rise of smart construction became a serious issue in South Korea. Korean government regards smart construction as a key for better productivity and more successful achievements for construction industry. In this extent, much efforts are being made in government levels. For example, the Ministry of Land, Infrastructure, and Transport (MOLIT) has established the 'Smart Construction Technology Roadmap' and 'The 6th Basic Plan for the Promotion of Construction Technology', and formed a smart construction project group for technology development in the construction field [13]. This effort will strengthen the promotion of smart construction and establish an ecosystem for improvement and innovation for field applications. In addition, MOLIT announced the 'Smart Construction Technology Field Application Guidelines' in March 2021 to activate new construction technology [14]. Other government organizations, such as Korea Expressway Corporation was selected as the general organization of the 'Smart Construction Technology Development Project for Road Demonstration' in April 2021, with the goal of innovative improvement of construction productivity and stability in road planning and construction [15]. Korea Railroad Corporation established a plan to improve safety management methods by using advanced technology in an integrated smart railway safety management platform [16]. Smart construction became a very popular topic in construction industry as it would improve working environment, risk management, and field safety. At the same time, it provides digitalized working environment from planning to operation and maintenance stage, which in return, will show a better productivity and efficiency.

In general, a construction project involves a number of steps from planning and designing to construction and maintenance stages. As a data management tool, BIM can be applied in every step of the process because of its 3D modeling capacity, data utilization and modification, and visualization abilities. A wide range of tools are developed to support BIM environment and international vendors provide a number of choices. Popular examples will be Revit, ArchiCAD, Trimble Connect, and so many. BIM was initially utilized in private sectors first because of its handy way of 3D representation and data association. Lately, however, public entities, such as government bodies, procurement organizations, and public administrations are actively adopting BIM because of its enhanced job ordering and project delivery capability.

There have been a large amount of studies elaborating the benefits of using BIM in the construction industry. In less than 10 years, more than 900 studies regarding BIM utilization are published as academic papers, and most of them illustrate how BIM could change the construction industry and the world at large [17,18]. Among various studies, many have shown a great interest on how effective BIM is, and a large amount of efforts have been put to identify the benefits in using BIM $[5,6,17,18]$. The benefits of utilizing BIM can be divided into five categories: (1) lifecycle cost control; (2) effective construction process; (3) design and quality improvement; (4) decision-making support; and (5) risk management, and some are more abundant in specific cases, such as facilities management [4,19-22].

However, some studies have revealed a critical notion in organizational and institutional issues of using BIM. A study has analyzed that knowledge management is an important issue in automated construction environment. A significant increase in the level of influence of coordination and integration, strategic direction and intend, organizational learning and creating change on knowledge management in a BIM-enabled environment compared to traditional construction environment. The statistical results revealed that coordination and integration are effective in integrated engineering, clash detection, model 
updates, integrated logistics, soft landing plans and as-built models for trade coordination or on-site construction when coupled with BIM [6,18,22,23].

A study on Indian architectural firms also analyzed that there are some critical management issues that need to be pre-adjusted before using BIM in a real project [24]. A proper management support is one of the major drivers for BIM adoption. A total of $75 \%$ of BIM adopters and 50\% of non-adopters have reported that top management in their firm has always shown an interest in the implementation of BIM. Along with this, 74\% of BIM adopters and $42 \%$ of non-adopters have also mentioned that top management in their organization has effectively communicated their support for BIM implementation. However, the biggest hurdle for adopting BIM in management perspective is in its cost. Although management recognizes and has tendency to use BIM for their firms, the cost of utilizing BIM and maintaining it seems reasonably high and makes people to actually do implementation. [24]. In terms of value proposition, studies have identified that there are some advantages of using BIM and the results are acknowledgeable. Recent study about the influence of BIM benefits from the Malaysian construction stakeholders has analyzed that productivity, time, cost, clashes, and communication are the most essential BIM benefits that concerned the participants $[25,26]$. The driving factors of implementation, on the other hand, were selected as trust, respect, commitment, early involvement, and knowledge. It is also found that there is a significant relationship between BIM benefits and its implementation $[25,26]$.

Another study has found that the implementation of BIM in a real project is not limited to the technical aspects but is also about organizations, regulations, and managerial affairs [27]. Enhancing BIM in architecture, engineering, and construction (AEC) projects requires push-pull strategies, implementing BIM in projects faces the resistance of organizational culture, and adopting BIM brings institutional changes to projects. Regarding the latent factors, the enhancement of current BIM implementation requires the accommodation of changes in project context by institutional governance. It can be triggered by leadership and sustained by ad hoc settings in the project context regarding technical, organizational, and financial conditions [28-30]. Other studies have revealed that governmental employees held more conservative perceptions toward certain benefits, critical factors, and challenges in BIM practice, such as BIM benefits in human resources, project feature, and number of BIM knowledgeable companies [31,32]. Study results indicate that smaller-sized organizations (i.e., with fewer than 100 full-time employees) held more positive views on BIM benefits in recruiting or maintaining employees, as well as the importance of having certain number of BIM knowledgeable employees in the project $[20,33,34]$.

As can be seen, although BIM provides positive aspects for construction industry, a number of studies have emphasized the importance for organizational efforts. In this extent, this study tries to identify what are the demands for a better BIM working environment for construction industry and AEC as a whole. Smart construction and BIM can be regarded as a relatively new terms in AEC industry and due to this reason, we are not so aware of how we should accelerate such advantages and how to support BIM environment in political and institutional ways. Not many studies try to precisely understand its fundamental demands and required administrative preparations for a healthier BIM environment. If BIM is an ideal tool for AEC productivity and eventually will lead us to a smarter construction environment, then there should be a thorough consideration regarding its institutional and administrative approaches. In this extent, the main purpose of this paper is to understand the barriers and facilitators that are raised by real professionals for a successful BIM implementation.

\section{Materials and Methods}

To properly understand the working environment of BIM in AEC industry, the authors conducted an in-depth survey with relevant professionals. A survey with 40 questionnaires was distributed to 100 professionals in construction, design, engineering, government, and rail industry. Among 100 surveys, 65 were returned with proper answers, 22 were returned with missing answers and 13 were not returned because of various reasons. The survey 
was delivered through an email to professionals working in AEC industries, especially railway environment. These experts were chosen based on the work scope written in employers' website. In addition, some part of the respondents was also contacted based on other expert's recommendations and the authors' individual network. The survey was conducted on October 16 to December 16 in 2020.

Table 1 indicates the list of questions distributed to respondents. As can be seen, question 1 through 7 ask about basic information regarding each respondent. Although respondents were chosen specifically in AEC industries, their role, familiarity with BIM, years of experience, and other background differ to a certain degree. The second part of the survey is related to BIM education and knowledge management. As BIM is a relatively new field, not many people in the industry received formal education. Rather, they have learned $\mathrm{BIM}$ as a tool that is regarded as an extension to 2D computer-aided drawing (CAD). This second part is designed to identify if systematic education is required to properly conduct BIM assignments in rail and AEC industry at large. In addition, respondents were asked if a certificate system is required for a better BIM working environment. Currently in Korea, there is a certificate system for BIM implementation but the system does not guarantee economic valuation yet. It means the certificate only supports whether the person can handle BIM works, not representing financial stability in exchange. Therefore, the authors asked the professionals if certificate system is in demand and whether knowledge sharing platform is required.

Table 1. Survey Design and Delivered Questionnaires.

\begin{tabular}{|c|c|c|}
\hline Fields & No. & Questions \\
\hline \multirow{8}{*}{ Basic Information } & 1 & Age group \\
\hline & 2 & Work Professions \\
\hline & 3 & Experience (years in industry) \\
\hline & $3-1$ & Rail industry experience \\
\hline & 4 & Type of Organization working for \\
\hline & 5 & Specific Job Description \\
\hline & 6 & Familiarity with BIM \\
\hline & 7 & Relevance of BIM to project \\
\hline \multirow{11}{*}{ BIM Education \& Knowledge Sharing Platform } & 1 & BIM Education \\
\hline & $1-1$ & Duration of the education \\
\hline & $1-2$ & Education materials \\
\hline & 2 & Demand for Formal BIM Education \\
\hline & $2-1$ & Length of proper BIM education \\
\hline & $2-2$ & BIM education contents \\
\hline & 3 & Necessity of a BIM Certificate System for AEC Industry \\
\hline & $3-1$ & Required BIM certification in rail industry \\
\hline & 4 & Exposure to BIM Knowledge \\
\hline & 5 & Relevance of BIM Knowledge Sharing Platform to Work \\
\hline & 6 & Contents for Knowledge Sharing Platform \\
\hline
\end{tabular}


Table 1. Cont.

\begin{tabular}{|c|c|c|}
\hline Fields & No. & Questions \\
\hline \multirow{18}{*}{ BIM for Design and Construction } & 1 & Advantage of Using BIM in Design Stage \\
\hline & $1-1$ & Most relevant work of using BIM in design stage \\
\hline & $1-2$ & Obstacles of using BIM in design stage \\
\hline & $1-3$ & Role of BIM professionals for design stage \\
\hline & $1-4$ & Required level of expertise for BIM professionals \\
\hline & 2 & Advantage of Using BIM in Construction Stage \\
\hline & $2-1$ & Most relevant work of using BIM in construction stage \\
\hline & $2-2$ & Obstacles of using BIM in construction stage \\
\hline & $2-3$ & Role of BIM professionals for construction stage \\
\hline & $2-4$ & Required level of expertise for BIM professionals \\
\hline & 3 & Most Wanted BIM Work for Railway Design \\
\hline & 4 & Most Wanted BIM Work for Railway Construction \\
\hline & 5 & Using BIM for Quality Management of a Project \\
\hline & 6 & Advantages of BIM in Ordering and Procurement \\
\hline & 7 & Difficulties of Using BIM in Ordering and Procurement \\
\hline & 8 & Necessity of Proper Compensation System for BIM Use \\
\hline & $8-1$ & Appropriate compensation for BIM use in design stage \\
\hline & $8-2$ & Appropriate compensation for BIM use in construction stage \\
\hline
\end{tabular}

The third part concerns the use of BIM in planning and construction stage. The questionnaires were specifically related to planning and construction, identifying obstacles, benefits, and requests from each respondent. As seen in Table 1, the use of BIM was asked in general context at first, and then some specific questions were delivered regarding railway industry for more detailed answers. There are some parts of the survey specifically designed to accommodate answers for government order systems in rail industry. Because most of railway projects are conducted from public side, governments are the biggest players in procurement and ordering systems. In this extent, respondents were asked if BIM can help facilitate public ordering and procurement process and if there are any anticipated obstacles in BIM implementation in public side. This part also concerns about a proper compensation of using BIM in AEC industries.

\section{Results}

\subsection{Basic Information}

According to the survey results, the majority of respondents are in between the 30 s and $40 \mathrm{~s}$, a total of $84 \%$ from the entire respondents. Regarding their backgrounds, $56 \%$ of respondents were coming from civil engineering background, $14 \%$ are from electrical and mechanical engineering, $4 \%$ are from architecture, and $2 \%$ are not directly related to AEC industries. In terms of affiliations, about $50 \%$ are coming from government bodies mostly relating to job ordering and procurements. About $25 \%$ are coming from BIM firms, where their works are mainly about BIM making and management, about $15 \%$ of respondents are from construction, and less than $7 \%$ are from architectural firms. As a consequence, the majority of the respondents' work scope relates to BIM creation and management, about $17 \%$ relates to procurement and job ordering, $15 \%$ are in architecture jobs, and about $2 \%$ relates to actual construction. In terms of the number of experience, about $36.7 \%$ shows less than 5 years in the industry, about $20 \%$ have 5 to 10 years' experience. About $42.8 \%$ from the respondents show longer than 10 years of experience in the industry. This could be interpreted that most of respondents from this survey is coming with a decent background 
and could indicate that most of them started their career long before BIM was implemented in actual practice. The authors asked more specifically about respondents' experience in rail projects and about $62 \%$ of the respondents show less than 5 years of experience in railway projects. About $22 \%$ answered that they have longer than 10 years of experience in railway industry. Figure 1 illustrates respondents' affiliations and experience levels.
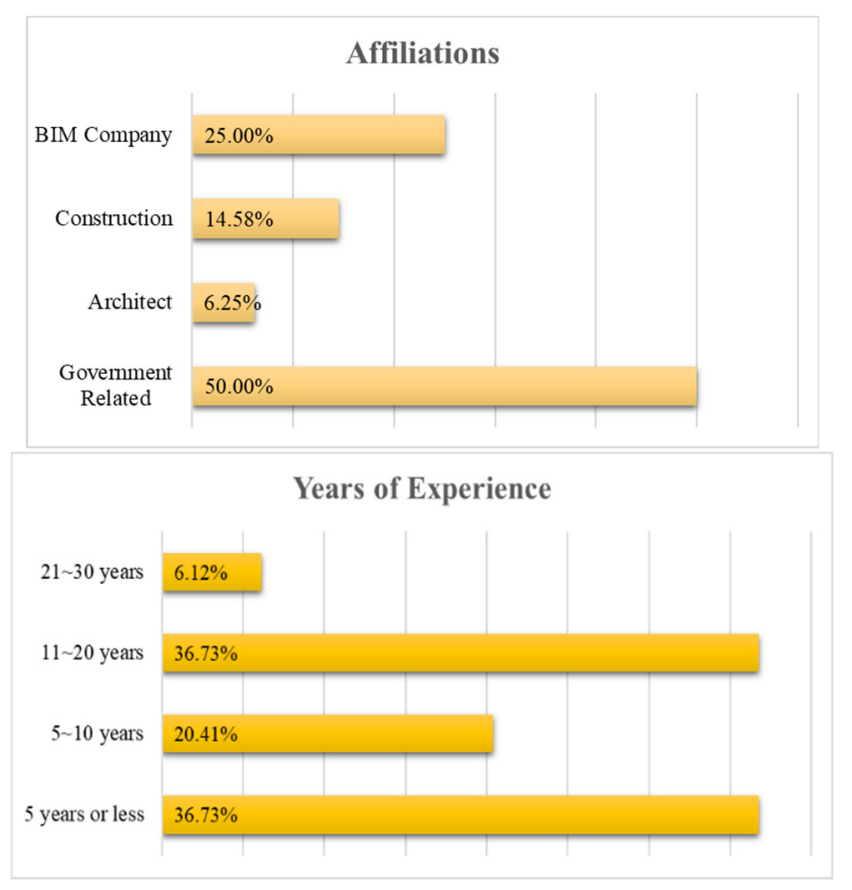
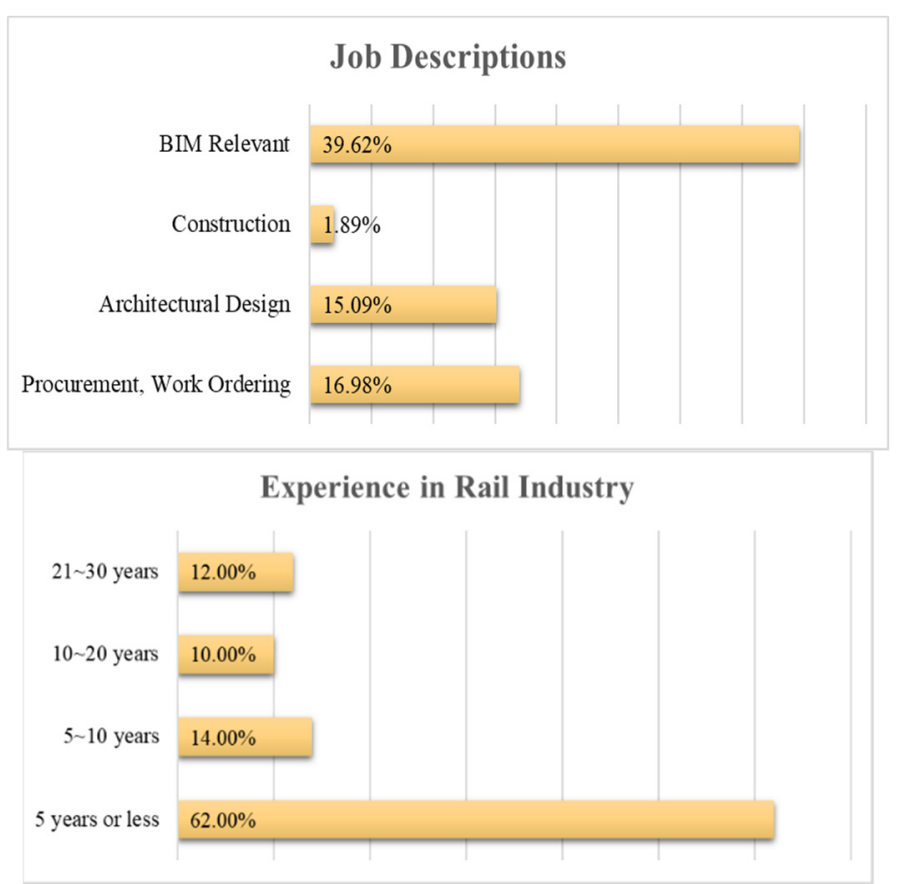

Figure 1. Respondents' Professional Backgrounds and Years of Experience.

In terms of respondents' familiarity with BIM, about $29 \%$ answered they do not know or not familial with BIM at all. The majority, about $43 \%$ showed they have moderate knowledge in BIM and this relates to just 3D working environment, not BIM as a complete data management platform. Among answers, about $17.6 \%$ responded that they know BIM very well and it means that only less than $20 \%$ of respondents understands BIM as a tool with nD capability. In terms of respondents' relativity of their works with BIM, about $43 \%$ replied that their works have low to very low connection to BIM. On the other hands, about $24 \%$ from the respondents' showed moderate to high relevance of BIM to their works. The results show an interesting result that most of respondents hold reasonably longer experience in their industry but less than half of them are familiar with BIM or their works are not directly related to BIM in general. Then the question becomes, if they are not very familiar with BIM environment, then would they be interested in learning? Or more precisely, do we have some kind of consensus that BIM is a necessity for a better AEC working environment? The second part of the survey answers these concerns.

\subsection{Education and Certificate System}

Whether the respondent has received BIM education previously, about $55 \%$ answered that they have no formal education regarding BIM. This seems an interesting result because based on previous survey results, only about $24 \%$ from the respondents denoted that their work has moderate to high relevance to BIM. In other words, there are more people who received formal BIM education ( $45 \%$ ) but not using in their real working environment. Looking at education experience more closely, $40 \%$ of respondents received education for less than 1 week and only $4 \%$ had a continuous BIM education for longer than 6 months. Some of the written answers identified that most of 1-week education involves very basics about BIM tools, such as Revit, Archicad, or Bentley, meaning that it could be closer to a modeling education, not for BIM as an information platform. 
Although almost half of the respondents answered that they have received formal BIM education and less than $30 \%$ indicated that their work has a relevance to BIM, more than $90 \%$ of the respondents agreed that AEC industry professionals need formal education regarding BIM. In addition, their intention about BIM education length shows that $32 \%$ answered 1 month is enough and $40 \%$ answered that 1 to 6 months are necessary length for proper BIM education. It seems that the professionals in AEC industry largely agree on BIM as a necessity requiring formal education. Many have identified that 1 week of education, which was the largest portion for BIM education from the respondents, is not enough, requesting for longer term. Some of the written answer indicated that they need more than just modeling education and there is a strong demand for learning BIM as an information platform that can manage entire project.

As can be seen in Figure 2, more than $75 \%$ of the respondents agreed that there should be a certificate system for BIM professionals. Whether the certificate is about design, engineering, or construction, the professionals have consensus about making BIM as a professional field that needs government-managed certification system for a better utilization. Regarding the items that needs certification, the answers indicate that about $27 \%$ requested there should be a certificate for BIM software utilization, whereas $30 \%$ emphasized that a certificate should be given for project management using BIM. About $20 \%$ of the respondents answered that design certificate should be integrated with BIM modeling ability and $13.6 \%$ answered that BIM certificate needs to be given for construction process. Therefore, it could be regarded that professionals understand BIM certificate is required and more emphasis should be given to project management with BIM ability not just for software utilization. This is an intriguing result as it seems that many professionals now understand BIM as a management and information tool, rather than just a software.

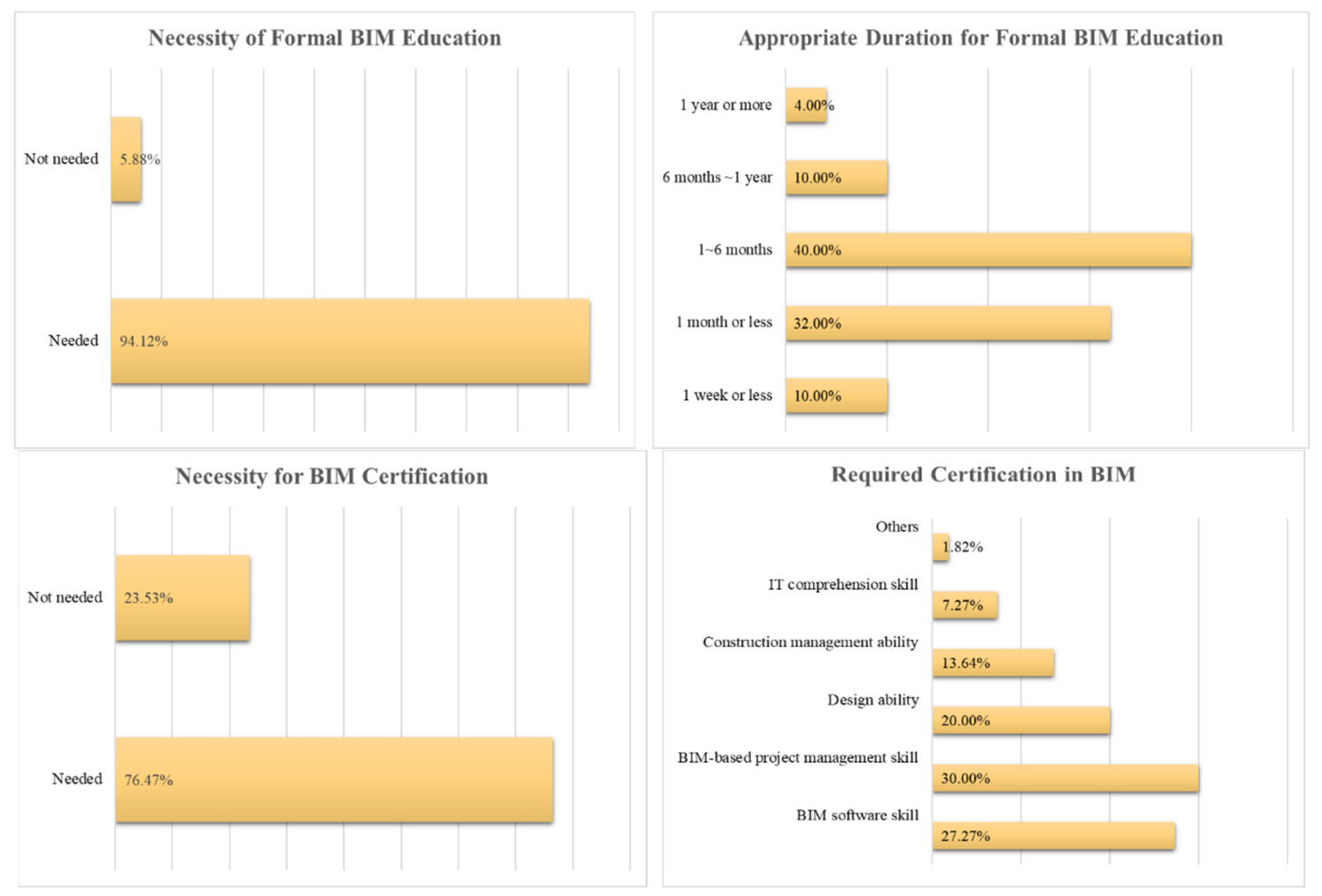

Figure 2. Responses about BIM Education and Certificate System.

Regarding the main resources for BIM information, the majority of Korean engineers rely on education and individual connections. As can be seen in Figure 3, about $29.8 \%$ of the respondents indicated that they obtain information regarding BIM through internal and external education from the organizations and about $24 \%$ answered that they individually 
contact associated professionals for more information. International websites and journal articles are about $37 \%$ of their BIM resources. Although there are various resources about BIM online, still many experts rely on traditional education format or in-person contacts. This can be divided into age structure because most of the respondents from age 30s and 40s showed international and domestic websites as the main resources for BIM information and most of people with a tendency for traditional education came out to be older than 50s cohort.

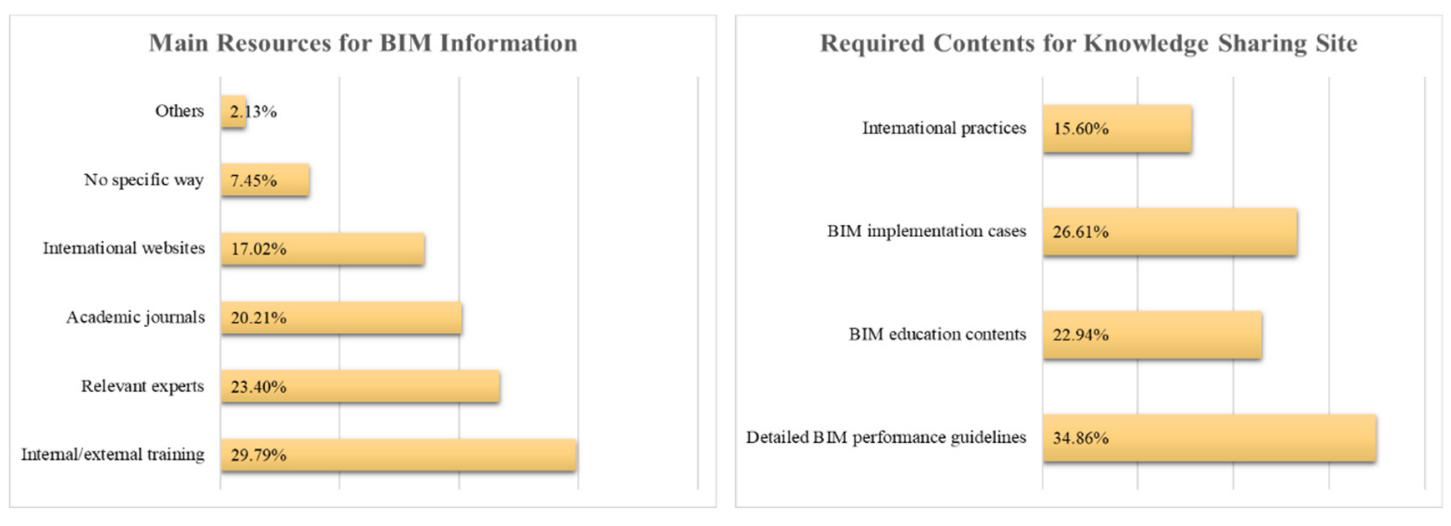

Figure 3. Preferences on BIM Knowledge Sharing Site.

Another good perspective regarding BIM information can be found on the respondents' preference on knowledge sharing platforms. According to the results, more than $72 \%$ of the answers revealed that knowledge sharing site will be of moderate to great help for their work. Only less than $6 \%$ of the respondents have answered that some form of a knowledge sharing site would be less helpful. In terms of specific contents, about $35 \%$ have identified that a specific guideline for BIM progress will be necessary and about $27 \%$ have indicated that sharing successful BIM implementation (i.e., case studies) will be helpful. Similar portion, about $23 \%$ have shown a great interest on education materials and about $16 \%$ need more in-depth information about international practices. Although most of the respondents have experienced BIM in a more traditional way, their tendency to learn and gather further information is inclined to knowledge sharing platform. A large portion of the respondents have agreed on the usefulness of the platform and the contents require a diversity from specific guidelines to educational materials. Figure 3 is a summary about knowledge sharing platform questionnaires.

\subsection{The Utilization of BIM}

The third part of the survey directly relates to the advantages and obstacles in BIM implementation. Questionnaires are largely divided into 5 sections: (1) BIM in design stage, (2) BIM for construction, (3) BIM in railway projects, (4) quality management and procurements, and (5) proper compensation for BIM specialists. According to the survey results, the respondents generally agrees with the advantages of using BIM whether it's in design, construction, or railway projects. Specific answers slightly differ to a certain degree but general consensus can be found for BIM implementation.

According to the result, about $30 \%$ of the respondents have answered that the biggest advantage of using BIM during designing stage can be found in error reduction. Because of model checking ability and 3D working environment, BIM can greatly reduce interference of structural, mechanical, electric components. This in return can provide enhanced efficiency during designing stage. The second biggest asset for using BIM in design is its automated process. Because BIM is an object-based process, drawings and other associated materials, such as the amount of steels, concrete, and other materials can be automatically calculated from design. About $20 \%$ of the respondents have showed that 3D modeling capacity is a great advantage of using BIM and 13\% indicated that time reduction in designing is a positive factor of using BIM during design stage. As a result, similar portion 
of respondents can be found for their wanting job boundary for BIM utilization. About $35 \%$ answered BIM is wanted during error checking stage and $27 \%$ require BIM for an automated process for design production.

The biggest obstacle in BIM for design can be found in vague standards for its production guidelines. About $41 \%$ answered that the government or any other procurement bodies should provide more specific and clearer standards for the final output. In other words, unclear job orders from the clients make engineers harder for using BIM. Another negative factor for using BIM is in its limited capability for human resources. About $26.2 \%$ of the respondents have identified that there is a lack of experienced professionals using BIM for design. Because of this reason, BIM designers are not properly utilized during design stage. Another notable answers are the increased cost of using BIM (11.9\%) and a lack of necessity for BIM because of familiarity to traditional working environment (16.67\%). For the level of expertise in BIM during design stage, less than $5 \%$ have answered that just a BIM modeler is required. As can be seen in Figure 4, many respondents showed that both BIM modeler and coordinator is required and about 19\% of answers even showed BIM manager is more required than BIM modeler level. This results can be interpreted that people see BIM professional more of a manager or coordinator than just a modeling professional.

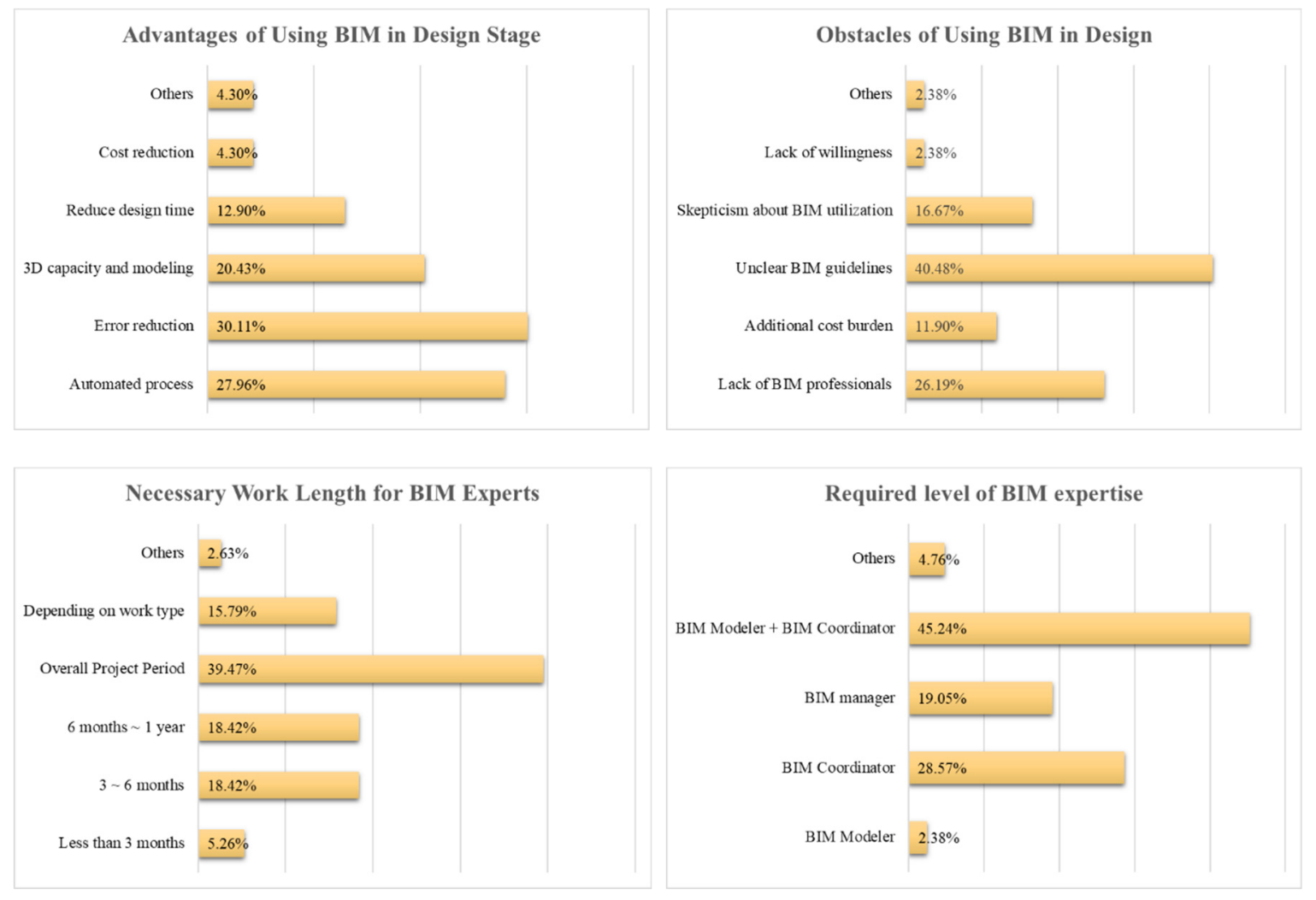

Figure 4. Preferences on BIM during Design Stage.

In terms of using BIM for construction stage, about 32.3\% have answered that BIM plays a positive role in detecting designing errors. During construction, finding an error can become a critical issue because if the model contains an error, whether it is a structural, mechanical, or else, there should be a reorder to be made and it eventually increase the length and costs of the project. In Figure 5, about 19.2\% answered that using BIM can increase construction ability which in return, promotes construction efficiency. About $10.6 \%$ answered that BIM facilitates construction budgeting and about $12.8 \%$ reported that it is a convenient tool in design change. This result can be found similarly in a question regarding which task should BIM be applied in construction. The majority of answers indicated that $\mathrm{BIM}$ is required for construction ability and design errors. One interesting observation 
is that many respondents answered that BIM needs to be used more in scheduling and cost management.
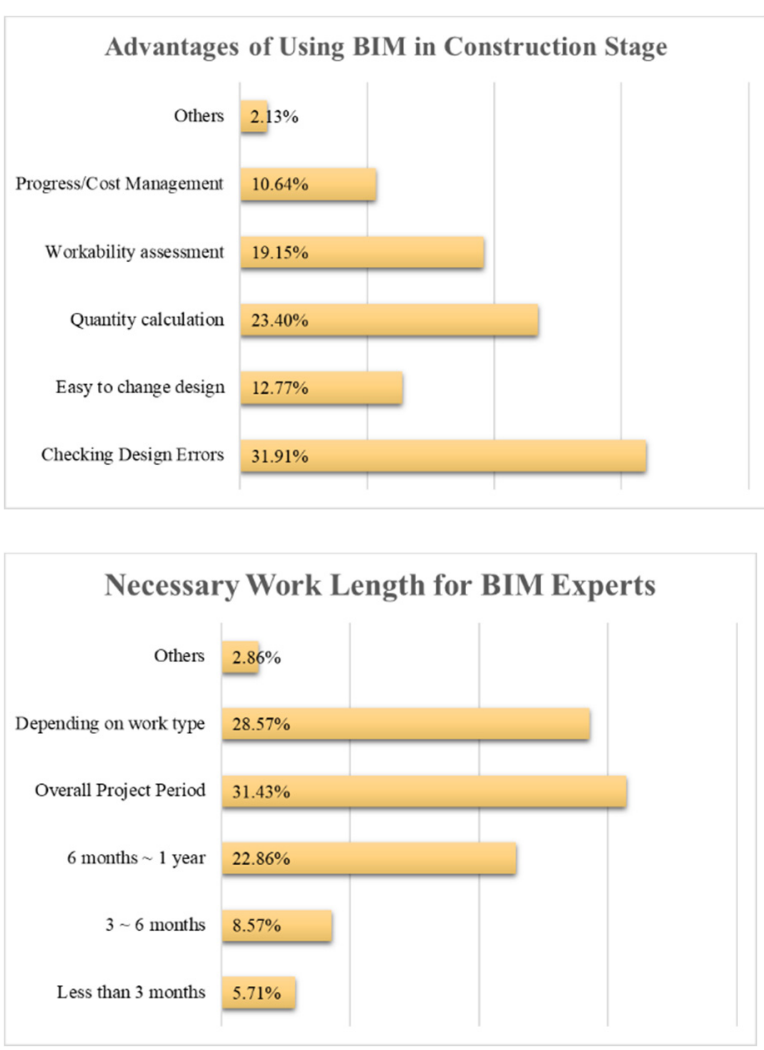
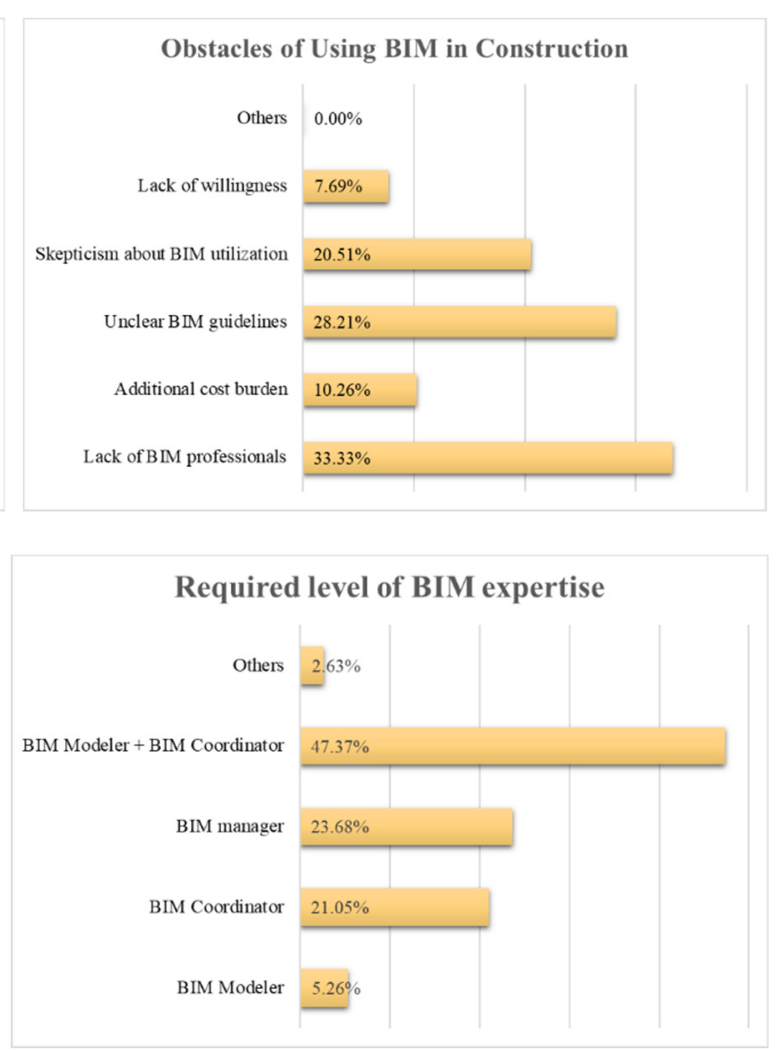

Figure 5. Preferences on BIM during Construction Stage.

When respondents were asked about the biggest obstacles in using BIM for construction, the answers show little variances. Each of the answer shares similar portion. A lack of experienced professionals and vague standards for production guidelines are two biggest obstacles in BIM for construction. Another factors prohibiting BIM is in a lack of necessity among construction professionals (20.51\%) and increased costs of using BIM (10.26\%). However, unlike BIM in design survey results, the difference between answers are not very significant. It seems like there are more various reasons for adopting BIM in construction than during design stage. For the level of expertise in BIM for construction, the dominant answer was a combination of modeler and coordinator. Similar pattern was observed in design and based on this observation, more experienced BIM experts are in demand for both design and construction processes.

More detailed questions were given to understand how BIM is acknowledged for railway professionals. As seen in Figure 6, when railway professionals were asked about what are needed for railway designing using BIM, about $21 \%$ have answered that there should clearer and more specific work standards. This is similar to the previous answers and it could be regarded that many experts are requiring for more specific working standards for procurements and public job orders. The second answer shows that there should be more BIM education available, especially for rail industry, and people were expecting a proper compensation for BIM utilizations. Similar notions could be found for BIM in construction stage. The largest portion of the answer indicates that there should be clear job identifications and specific work standards and there should be a proper compensation system for using BIM in a rail project. An interesting answer can be found in a dedicated BIM professional in the field. About $16 \%$ answered that there should be a dedicated BIM expert for field operation and this is the second most request from the respondents. 


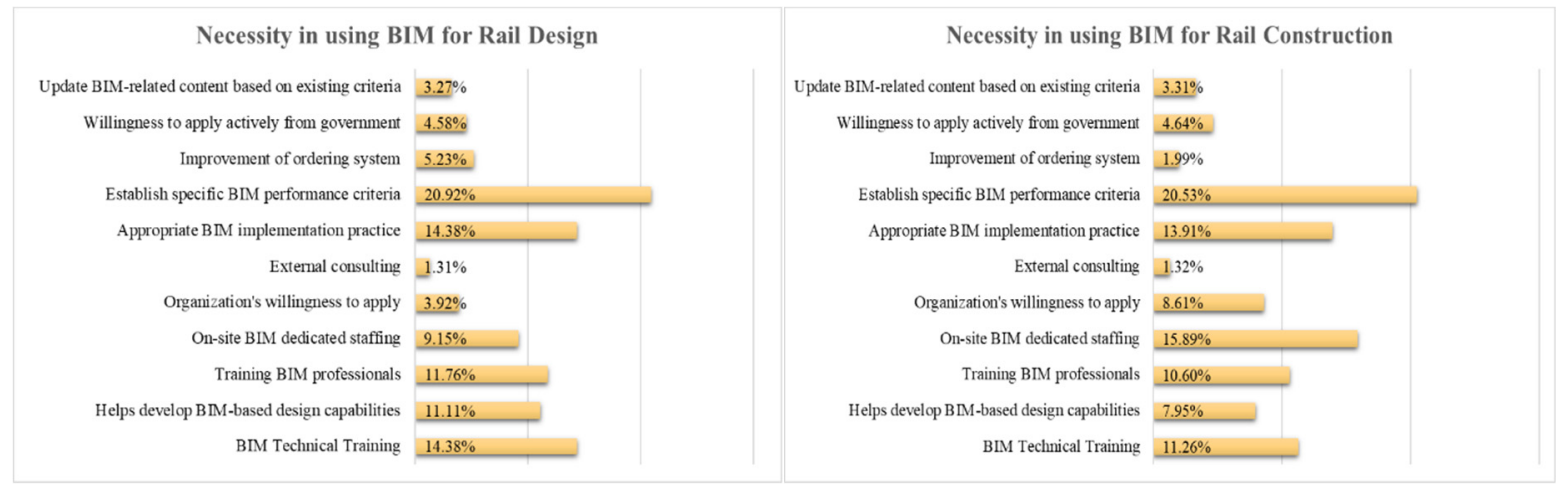

Figure 6. Preferences on BIM for Rail Industry.

From the government's perspective, the authors have asked what are the most necessary part of using BIM in project contract and procurement process. The majority of the respondents have answered that design errors are the biggest asset in job ordering $(38.2 \%)$. In addition, database creation and management is the key to successful contract management and system operation for a better maintenance (30.9\%). On the other hand, the respondents answered that the biggest obstacle for government to use BIM is in its lack of understanding about BIM. Similar to working experts, the government professionals also have showed that more specifications should be prepared for BIM project delivery.

The last part of the survey was designed to accommodate respondents' opinion on compensation system. The majority of the respondents have shown interests on a proper compensation for using BIM. About $80 \%$ of the answers have showed that there should be compensation for adopting BIM experts, such as a modeler or a coordinator. About the compensation rate, however, the answers showed a diverse range. About $27.7 \%$ have revealed that the rate for BIM experts should be negotiable with a fixed range and $23.4 \%$ have answered that it should be on actual usage-basis, closer to a man-hour basis. Other answers showed interests on 10 to $20 \%$ increase in total design fee $(19.15 \%)$ and about $12.77 \%$ have answered that the entire design fee needs 20 to $30 \%$ increase for using BIM. As seen in Figure 7, construction experts think the compensation for using BIM needs to be based on actual costs associated with BIM implementation (41.03\%). About $23.1 \%$ have answered that BIM for construction needs to be adjusted based on the percentage to the total construction fee. Although the system for paying BIM implementation showed a slightly different notion between design and construction, there is a strong demand for a proper compensation system when adopting BIM in AEC industry.

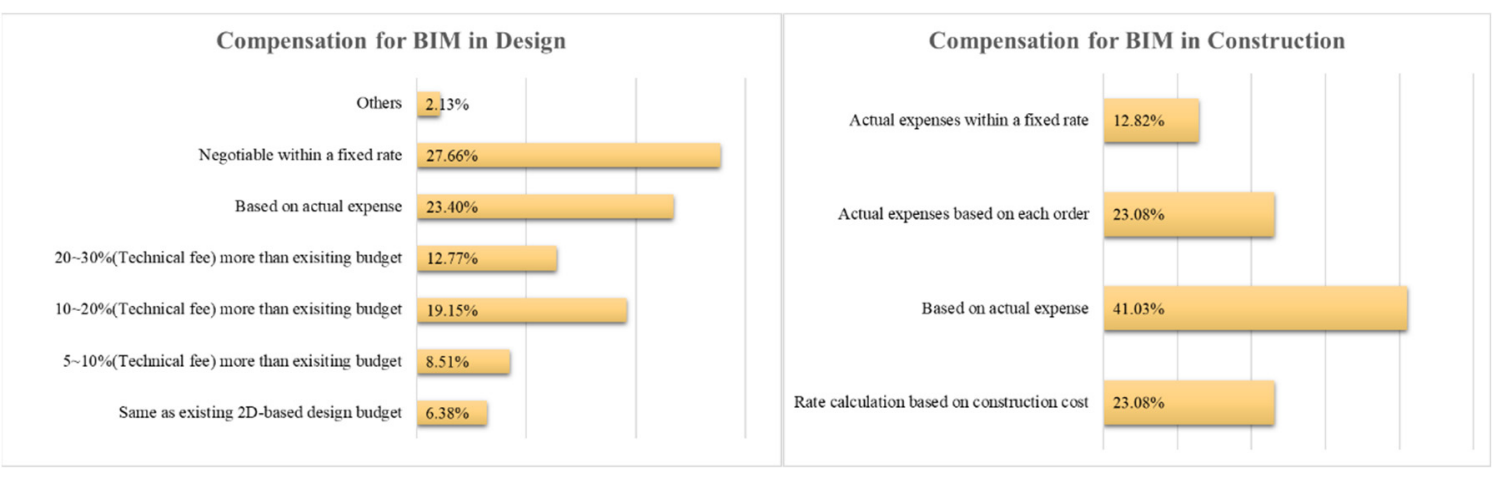

Figure 7. Preferences on BIM Compensation.

\section{Conclusions}

This study is designed to understand BIM utilization in design and construction process for AEC industry. In specific, questions are delivered to analyze relevant professionals' 
current understanding on BIM, their acknowledgement about education and knowledge sharing, and finally obstacles and compensation for successful BIM implementation. As the analysis indicated, although BIM seems to be in its early stage for more active involvement, there are quite many professionals already using BIM for their work. Especially, during designing and construction stage, many experts try to use BIM for a multi-purpose working environment.

However, there are still a large amount of gap between BIM use and relevant professional's level of expertise. Although $45 \%$ of the respondents have received a certain form of BIM education, more than $94 \%$ of the respondents have required there should be a formal education regarding BIM and the length of the education should be 1 to 6 months, which is significantly longer than the current education experiences. In addition, more than $76 \%$ of the answers have identified that there should be a certificate system for BIM experts and it needs to be more than just a modeling certificate. It should be also connected to project management and project implementation at large. More than $70 \%$ of the respondents have positive attitude toward knowledge sharing platform and the most demanding contents are specific guidelines and education materials for BIM.

According to the survey result, both design and construction experts have reported that the biggest advantage of using BIM is in its error checking ability. It can reduce design errors and increase construction ability for participants. Both design and construction experts are in high demand for specific work guidelines and more detailed procurement and project delivery. They have also denoted that a lack of professionals for BIM modeler and coordinator in AEC industry is another obstacle. This perception was relatively similar for rail industry professionals. Specific questions regarding rail industry showed a similar result as they require more detailed work guidelines and more dedicated professionals for BIM delivery. From the government side, they expect data delivery and management as a big asset in BIM utilization. Additionally, more than $79 \%$ of the respondents agreed upon a proper compensation system for BIM implementation. Although compensation allocation differs to a certain degree between design and construction, the majority of opinions have revealed that there should be an increase in construction and design fees for a proper BIM adjustment.

As many have noted, BIM can change AEC industry with many advantages. In specific, relevant professionals expect error reduction and data management as two biggest assets. Examining the survey result more specifically, regardless of age, professional backgrounds, affiliations, years of experience, and BIM education, most of the respondents have agreed that AEC industry should adopt BIM for a better productivity and efficient project management. There are, however, some differences among stakeholders, industries, and other perceptions and for that reason, BIM should be adjusted for its own industrial standards. Nonetheless, a vast amount of answers has accentuated that there are a number issues for a successful BIM application: (1) guidelines and details for BIM work and delivery; (2) more standardized BIM education; and (3) a proper compensation system for BIM work. These results show that BIM professionals are ready to adopt the consequences of using BIM, but administrative and political preparations are not available beforehand. Specific guidelines for project delivery, standardized education, and compensation all relate to systematic and organizational efforts. Many have noted the importance of using BIM in a very technical perspective. Now, we need to take BIM implementation to higher level of regulatory concerns and have to provide administrative solutions for successful BIM applications.

This study has revealed possible issues and requirements of using BIM for Korean AEC industry. Korean AEC industry is experiencing a rapid change for its better productivity and the authors believe the result of this study could give an insight about possible preparations for future smart construction environment. BIM is now regarded as an effective tool by relevant professionals. Then it is about time to think more thoroughly about institutional efforts that will help a successful working environment. Further studies should elaborate more about BIM and other data management packages, such as GIS 
or Artificial Intelligence. In addition, proper compensation system and more details on knowledge sharing platform will be a key to a successful BIM implementation.

Author Contributions: M.-H.S. prepared the entire research framework and managed the manuscript; H.-Y.K. has prepared initial data, analysis check, and manuscript submission. Both authors have read and agreed to the published version of the manuscript.

Funding: This study was funded by the Ministry of Land, Infrastructure, and Transport in South Korea (Grant number: 21RBIM-B158173-02) and also funded by internal research grants from Woosong University.

Institutional Review Board Statement: Not applicable.

Informed Consent Statement: Not applicable.

Conflicts of Interest: There is no conflict of interests.

\section{References}

1. Ahuja, R.; Sawhney, A.; Jain, M.; Arif, M.; Rakshit, S. Factors influencing BIM adoption in emerging markets-The case of India. Int. J. Constr. Manag. 2020, 20, 65-76. [CrossRef]

2. Chen, B.; Liu, A.M.; Hua, Y. An exploration of the interaction between BIM technology and the business process of a construction organization in BIM implementation. WIT Trans. Built Environ. 2017, 169, 177-189.

3. Dakhil, A.; Underwood, J.; Shawi, M. BIM benefits-maturity relationship awareness among UK construction clients. In Proceedings of the First International Conference of the BIM Academic Forum, Glasgow, UK, 13-16 September 2016.

4. Edirisinghe, R. Digital skin of the construction site: Smart sensor technologies towards the future smart construction site. In Engineering, Construction and Architectural Management; Emerald Publishing Limited: Bingley, UK, 2019.

5. Enshassi, A.A.; Hamra, L.A.A.; Alkilani, S. Studying the Benefits of Building Information Modeling (BIM) in Architecture, Engineering and Construction (AEC) Industry in the Gaza Strip. Jordan J. Civ. Eng. 2018, 12, 87.

6. Gbadamosi, A.-Q.; Oyedele, L.; Mahamadu, A.-M.; Kusimo, H.; Olawale, O. The Role of Internet of Things in Delivering Smart Construction. 2019. Available online: https:/ / uwe-repository.worktribe.com/preview/1492592/Gbadamosi\%20et (accessed on 22 September 2021).

7. Ghaffarianhoseini, A.; Tookey, J.; Ghaffarianhoseini, A.; Naismith, N.; Azhar, S.; Efimova, O.; Raahemifar, K. Building Information Modelling (BIM) uptake: Clear benefits, understanding its implementation, risks and challenges. Renew. Sustain. Energy Rev. 2017, 75, 1046-1053. [CrossRef]

8. Guerriero, A.; Kubicki, S.; Berroir, F.; Lemaire, C. BIM-enhanced collaborative smart technologies for LEAN construction processes. In Proceedings of the 2017 International Conference on Engineering, Technology and Innovation (ICE/ITMC), Madeira, Portugal, 27-29 June 2017.

9. Hong, Y.; Hammad, A.W.; Akbarnezhad, A. Impact of organization size and project type on BIM adoption in the Chinese construction market. Constr. Manag. Econ. 2019, 37, 675-691. [CrossRef]

10. Ibrahim, F.S.; Shariff, N.D.; Esa, M.; Rahman, R.A. The barriers factors and driving forces for bim implementation in malaysian aec companies. J. Adv. Res. Dyn. Control. Syst. 2019, 11, 275-284.

11. Jin, R.; Hancock, C.; Tang, L.; Chen, C.; Wanatowski, D.; Yang, L. Empirical study of BIM implementation-based perceptions among Chinese practitioners. J. Manag. Eng. 2017, 33, 04017025. [CrossRef]

12. Jo, J.; Choi, Y.W.; Lee, J.W.; Kim, H.Y. Using Survey information of BIM-applied Project—Construction Industry Specialist Interview. J. KIBIM 2020, 10, 33-42.

13. Korea Railroad Research Institute. Railroad Test and Certification. 2019. Available online: https://www.krri.re.kr/html/en/sub0 2/sub02_0206.html (accessed on 22 September 2021).

14. Lee, J. Environmental Factors of Acceptance Organization Affecting Intention to Accept Bim. Int. J. Manag. 2020, 11, 188-200.

15. Li, J.; Hou, L.; Wang, X.; Wang, J.; Guo, J.; Zhang, S.; Jiao, Y. A project-based quantification of BIM benefits. Int. J. Adv. Robot. Syst. 2014, 11, 123. [CrossRef]

16. Liao, L.; Lin, T.E.A. Organizational change perspective on people management in BIM implementation in building projects. J. Manag. Eng. 2018, 34, 04018008. [CrossRef]

17. Liu, D.; Lu, W.; Niu, Y. Extended technology-acceptance model to make smart construction systems successful. J. Constr. Eng. Manag. 2018, 144, 04018035. [CrossRef]

18. Malik, Q.; Nasir, A.R.; Muhammad, R.; Thaheem, M.J.; Ullah, F.; Khan, K.I.A.; Hassan, M.U. BIMp-Chart-A Global Decision Support System for Measuring BIM Implementation Level in Construction Organizations. Sustainability 2021, 13, 9270. [CrossRef]

19. Mesároš, P.; Smetanková, J.; Mandičák, T. The Fifth Dimension of BIM-Implementation Survey; IOP Conference Series: Earth and Environmental Science; IOP Publishing: Bristol, UK, 2019.

20. Ministry of Land Infrastructure and Transport. Construction Industry Vitality Enhancement Plans. Retrieved 2020.07 2019. Available online: http://www.molit.go.kr/english/USR/BORD0201/m_28286/DTL.jsp?id=eng_mltm_new\&mode=view\&idx= 2797 (accessed on 22 September 2021). 
21. Musa, S.; Marshall-Ponting, A.; Nifa, F.A.A.; Shahron, S.A. Building information modeling (BIM) in Malaysian construction industry: Benefits and future challenges. In AIP Conference Proceedings; AIP Publishing LLC: Melville, NY, USA, 2018.

22. Nam, J.; Kim, M.J. Object-oriented Road Field BIM Standard Object Classification System Suggest Development Plan. J. Korea Acad. -Ind. Coop. Soc. 2018, 19, 119-129.

23. Olawumi, T.O.; Chan, D.W. Identifying and prioritizing the benefits of integrating BIM and sustainability practices in construction projects: A Delphi survey of international experts. Sustain. Cities Soc. 2018, 40, 16-27. [CrossRef]

24. Raja Mohd Noor, R.N.H.; Ibrahim, C.K.I.C.; Belayutham, S. The nexus of key attributes influencing the social collaboration among BIM actors: A review of construction literature. Int. J. Constr. Manag. 2021, 1-11.

25. Reddy, H.G.; Kone, V. Study on implementing smart construction with various applications using internet of things techniques. In International Conference on Advances in Civil Engineering (ICACE-2019); Available online: https://www.researchgate.net/ profile/Venkatesh-Kone/publication/353322626_Study_on_Implementing_Smart_Construction_with_Various_Applications_ Using_Internet_of_Things_Techniques/links / 60f3fd460859317dbdee5afc/Study-on-Implementing-Smart-Construction-withVarious-Applications-Using-Internet-of-Things-Techniques.pdf (accessed on 22 September 2021).

26. Reizgevičius, M.; Ustinovičius, L.; Cibulskienė, D.; Kutut, V.; Nazarko, L. Promoting Sustainability through Investment in Building Information Modeling (BIM) Technologies: A Design Company Perspective. Sustainability 2018, 10, 600. [CrossRef]

27. Shin, M.H.; Lee, H.K.; Kim, H.Y. Benefit-Cost Analysis of Building Information Modeling (BIM) in a Railway Site. Sustainability 2018, 10, 4303. [CrossRef]

28. Štefanič, M.; Stankovski, V. A review of technologies and applications for smart construction. In Proceedings of the Institution of Civil Engineers-Civil Engineering; Thomas Telford Ltd.: London, UK, 2018.

29. Terreno, S.; Anumba, C.; Gannon, E.; Dubler, C. The benefits of BIM integration with facilities management: A preliminary case study. In Proceedings of the 2015 International Workshop on Computing in Civil Engineering, Austin, TX, USA, 21-23 June 2015; pp. 675-683. Available online: https:/ / ascelibrary.org/doi/10.1061/9780784479247.084 (accessed on 22 September 2021).

30. Tomek, A.; Matějka, P. The impact of BIM on risk management as an argument for its implementation in a construction company. Procedia Eng. 2014, 85, 501-509. [CrossRef]

31. Volk, R.; Stengel, J.; Schultmann, F. Building Information Modeling (BIM) for existing buildings-Literature review and future needs. Autom. Constr. 2014, 38, 109-127. [CrossRef]

32. Wong, J.K.W.; Zhou, J. Enhancing environmental sustainability over building life cycles through green BIM: A review. Autom. Constr. 2015, 57, 156-165. [CrossRef]

33. Yalcinkaya, M.; Singh, V. Patterns and trends in building information modeling (BIM) research: A latent semantic analysis. Autom. Constr. 2015, 59, 68-80. [CrossRef]

34. Yang, J.-B.; Chou, H.-Y. Mixed approach to government BIM implementation policy: An empirical study of Taiwan. J. Build. Eng. 2018, 20, 337-343. [CrossRef] 